\title{
Family Caregivers' Satisfaction towards the Communication of Health Service Providers in Tertiary Care Hospital of Nepal
}

\author{
Sonam Shrestha ${ }^{1}$, ${ }^{*}$ Basant Maharjan ${ }^{1}$, Swosti Acharya ${ }^{2}$, Manisha Dangol ${ }^{3}$, Sunil Shrestha ${ }^{2,4}$ \\ ${ }^{1}$ Kathmandu Model Hospital, Pradashini Marg, Kathmandu, Nepal \\ ${ }^{2}$ Nepal Health Research and Innovation Foundation, Lalitpur, Nepal \\ ${ }^{3}$ Civil Service Hospital, Minbhawan, Kathmandu, Nepal \\ ${ }^{4}$ Nobel College, Affiliated to Pokhara University, Kathmandu, Nepal
}

*Corresponding Author: Basant Maharjan; Email: basant06maharjan@yahoo.com

\begin{abstract}
Introduction: Patient and family caregivers' satisfaction is an essential measure of the quality of care and a determinant of health service utilization. Measuring family caregivers' satisfaction with health service providers is important for understanding and improving the quality of care at health facilities. Therefore, the present study aimed to assess the satisfaction of family caregivers towards the communication of health service providers.
\end{abstract}

Methods: A descriptive cross-sectional study was conducted by the development of a questionnaire at one of the tertiary care hospitals. Self-administered questionnaires related to demography and different dimensions on the satisfaction of caregivers towards the communication of health service provider was designed. Sixty caregivers were provided questionnaire and data was collected. In descriptive analysis, frequency and percentage were calculated using SPSS 23 (SPSS Inc., Chicago, IL, USA).

Results: The study showed that the majority of the caregivers (40\%) were of the young age group (31-40 years). More than half (53\%) of the caregivers were satisfied with different ways of communication about the patient's condition and treatment. In terms of communication mode, the majority of the caregivers were satisfied with related different ways of communication about the patient's condition and treatment $(53.3 \%)$ followed by verbal $(63.6 \%)$ and non-verbal $(50.6 \%)$ respectively during their stay at the hospital.

Conclusion: The current study found that caregivers were satisfied with the communication provided by health service providers. This suggests that the treatment provided to patients might have better outcome measures. Additionally, it may help to reduce the anxiety among caregivers regarding the patients' condition.

Keywords: caregivers, communication, health service provider, satisfaction

\begin{tabular}{|c|c|c|}
\hline \multicolumn{2}{|c|}{ Access this article Online } & \multirow{2}{*}{$\begin{array}{l}\text { Article Info. } \\
\text { How to cite this article in Vancouver Style? }\end{array}$} \\
\hline Quick Response Code & Website: & \\
\hline & www.jkahs.org.np & $\begin{array}{l}\text { Shrestha S, Maharjan B, Acharya S, Dangol M, } \\
\text { Shrestha S Family Caregivers' Satisfaction towards the } \\
\text { Communication of Health Service Provider in Tertiary } \\
\text { Care Hospital of Nepal. Journal of Karnali Academy of } \\
\text { Health Sciences. 2020;3(2): } 57-64\end{array}$ \\
\hline & $\begin{array}{l}\text { DOI: } \\
\text { https://doi.org/10.3126/ } \\
\text { jkahs.v3i2.31323 }\end{array}$ & $\begin{array}{ll}\text { Received } & : 24 \text { Feb } 2020 \\
\text { Accepted } & : 2 \text { Apr. } 2020 \\
\text { Published Online } & : 14 \text { Apr. } 2020 \\
& \\
\text { Conflict of Interest } & : \text { None; } \\
\text { Source of Support } & \text { : None }\end{array}$ \\
\hline
\end{tabular}




\section{INTRODUCTION}

Family caregivers, also known as informal caregivers, are particularly important for caring and assisting individuals with acute and chronic conditions during hospitalization. ${ }^{1}$ The priorities are given to the role of family caregivers, as they are directly involved in the decision-making process with patients' nearest ones. This ensures adequate support to patients that are associated with preventing the patients from the possible worse outcomes. Although this responsibility is accompanied by feelings of burden and anxiety among the family caregivers, it also prevents leading to dissatisfaction with care. ${ }^{2}$ This concern is usually addressed by the health service providers by educating the patients and collaborating with the patients and family caregivers. ${ }^{3}$

The importance of proper communication during patient care is related to the improvement of the nurse-patient interpersonal relationship; however, collectively helps in satisfying the patients. Good nurse-patient communication brings positive treatment outcomes and patient's perceptions of the quality of health care. This suggests that there is a strong link between proper communication and improved health outcomes for the patient., ${ }^{4,5}$ During the process of patient care, both verbal and nonverbal communication is equally important. ${ }^{6,7}$ Higher attention in patient satisfaction from the perspective of hospital care has been a topic of interest for many health researchers. There is an improvement in the level of satisfaction among patients with good staffpatient interpersonal relationships. ${ }^{89}$ Importantly, the issues of communication have been reported as complaints regarding medical doctors rather than their clinical competence. The diagnoses and treatment of the diseases should be dealt with proper communication. $^{10,11}$ As proper communication is important for patient satisfaction, the health service provider needs to know the related factor that influences caregivers' satisfaction towards communication. It is an important measure of the evaluation of a health service provider. ${ }^{12}$

Although studies are reporting the satisfaction level of patients with health service providers from Nepal, ${ }^{13-16}$ there is no evidence from Nepal reporting the level of family caregivers' satisfaction from health service providers. As Nepal is a multilingual country, the communication level and interaction of health service providers and patients/caregivers might be different. Therefore, the present study mainly aimed to assess the satisfaction of the family caregivers' towards the communication of health service providers.

\section{MATERIALS AND METHODS}

\section{Study design, sample size calculation}

A descriptive cross-sectional study was used to conduct the study comprising the patient's caregivers of the medical and surgical ward, whose individuals were admitted for 3-7 days at Kathmandu Model Hospital. This is the single-center study and family caregivers from in-patients, medical and surgical wards were only included.

Non-probability convenient sampling technique was used to select the sample and sample size was calculated as 60 as calculated by Slovin's formula ${ }^{17}$ based on total population size as 70 and with a margin of error as $5 \%$. Caregivers who were children and elderly above 60 years were excluded from the study.

\section{Ethical considerations}

Ethical approval was obtained from the local research committee, Institutional review committee (IRC) of Kathmandu Model Hospital (Ref No: 03/ $\mathrm{BL} / 2018)$. Written consent was obtained from the hospital authority. Before the data collection, formal permission was obtained from each respondent and they were informed about the purpose and objectives of the study. Privacy and confidentiality were maintained by not disclosing the name of the participants and ensuring them, that collected information was used only for the research purpose. Human rights and justice were maintained as respecting all respondents with due respect.

\section{Research Instrumentation and Data Collection}

The instrument (structured interview questionnaire) was developed by the researcher after extensive literature review and consulting with a statistician, subject experts and based on the objectives of the study Structured interview schedule was used containing two parts; 
i) Socio-demographic information including age, sex, marital status, educational status, religion, ethnic group, current working status and financial status.

ii) Question-related to communication and attitude.

\section{Validity and Reliability}

The validity of the structured questionnaire was maintained by developing the instrument based on objectives of the study, extensive literature review and consulting with a statistician, research and subject experts for accuracy and adequacy of the content. The questionnaire was developed in the English language and translated into Nepalese language to make it easy for the caregivers to answer. The reliability of the instrument tool was maintained by pretesting with $10.0 \%$ of the total sample size at Kirtipur Hospital. After pretesting, questions 2, 5 and 11 were simplified to make the questions easy for understanding for the respondents.

\section{Data analysis}

The collected data was edited, organized, coded and entered into SPSS Version 23 (SPSS Inc., Chicago, IL, USA) for the analysis. The data were interpreted in terms of descriptive statistics such as frequency and percentage.

\section{RESULTS}

Most of the participants were female (53\%), 31-40 years age group (40\%), highest as having secondary level qualification (35\%), speak the Nepali language $(82 \%)$ and were from Newar caste $(50 \%)$ and followed Hindu religion (85\%) (Table1).

\section{Socio-demographic information}

Table 1: Socio demographic information of respondents $(n=60)$

\begin{tabular}{|l|l|l|}
\multicolumn{1}{|c|}{ Variables } & \multicolumn{1}{c|}{$\begin{array}{c}\text { Number } \\
(\mathbf{N})\end{array}$} & $\begin{array}{c}\text { Percentage } \\
(\%)\end{array}$ \\
\hline Gender & & \\
\hline Male & 28 & 46.7 \\
\hline Female & 32 & 53.3 \\
\hline
\end{tabular}

\begin{tabular}{|c|c|c|}
\hline \multicolumn{3}{|l|}{ Age group (in years) } \\
\hline Below 20 & 1 & 1.7 \\
\hline $21-30$ & 23 & 38.3 \\
\hline $31-40$ & 24 & 40.0 \\
\hline $41-50$ & 10 & 16.7 \\
\hline $51-60$ & 2 & 3.3 \\
\hline \multicolumn{3}{|l|}{ Level of Education } \\
\hline Read and Write & 13 & 21.7 \\
\hline Basic Level & 11 & 18.3 \\
\hline Secondary Level & 21 & 35.0 \\
\hline $\begin{array}{l}\text { Higher Secondary } \\
\text { Level }\end{array}$ & 15 & 25.0 \\
\hline \multicolumn{3}{|l|}{ Language } \\
\hline Nepali & 49 & 81.7 \\
\hline Newari & 9 & 15.0 \\
\hline Tamang & 2 & 3.3 \\
\hline \multicolumn{3}{|l|}{ Ethnic Group } \\
\hline Newar & 30 & 50.0 \\
\hline Brahman/Chhetri & 23 & 38.3 \\
\hline Tamang & 6 & 10.0 \\
\hline \multicolumn{3}{|l|}{ Religion } \\
\hline Hindu & 51 & 85.0 \\
\hline Buddhist & 9 & 15.0 \\
\hline
\end{tabular}

Findings on the satisfaction of caregiver explaining about patient's condition and treatment

Overall, our result showed that half of the caregivers (53.3\%) strongly agree that they understand the patient's condition and treatment after communicating with the doctors. This is followed by agree (43.0\%), neutral $(2.0 \%)$, disagree $(1.4 \%)$ and strongly disagree $(0.3 \%)$ options (Table 2$)$. 
Table 2: Satisfaction of the caregiver towards explaining about patient's condition and treatment

\begin{tabular}{|c|c|c|c|c|c|c|}
\hline \multirow{3}{*}{$\mathbf{S . N}$} & \multirow{3}{*}{ Statement } & \multicolumn{5}{|c|}{ Opinion } \\
\hline & & $\begin{array}{l}\text { Strongly } \\
\text { Agree }\end{array}$ & Agree & Neutral & Disagree & $\begin{array}{l}\text { Strongly } \\
\text { Disagree }\end{array}$ \\
\hline & & $\mathbf{N}(\%)$ & $\mathbf{N}(\%)$ & $\mathbf{N}(\%)$ & N (\%) & $\mathrm{N}(\%)$ \\
\hline 1 & $\begin{array}{l}\text { It is easy to understand what } \\
\text { the doctor is talking to me } \\
\text { about my patient's condition }\end{array}$ & $\begin{array}{l}45 \\
(75.0)\end{array}$ & $\begin{array}{l}15 \\
(25.0)\end{array}$ & - & & - \\
\hline 2 & $\begin{array}{l}\text { The nurse explains the } \\
\text { procedure before performing } \\
\text { it. }\end{array}$ & $\begin{array}{l}37 \\
(61.7)\end{array}$ & $\begin{array}{l}21 \\
(35.0)\end{array}$ & $\begin{array}{l}1 \\
(1.7)\end{array}$ & $\begin{array}{l}1 \\
(1.7)\end{array}$ & - \\
\hline 3 & $\begin{array}{l}\text { Nurse response my question } \\
\text { properly when I ask about my } \\
\text { patient condition }\end{array}$ & $\begin{array}{l}25 \\
(41.7)\end{array}$ & $\begin{array}{l}32 \\
(53.3)\end{array}$ & $\begin{array}{l}1 \\
(1.7)\end{array}$ & $\begin{array}{l}1 \\
(1.7)\end{array}$ & $\begin{array}{l}1 \\
(1.7)\end{array}$ \\
\hline 4 & $\begin{array}{l}\text { Doctor response my question } \\
\text { properly when I ask about my } \\
\text { patient condition }\end{array}$ & $\begin{array}{l}18 \\
(30.0)\end{array}$ & $\begin{array}{l}40 \\
(66.7)\end{array}$ & $\begin{array}{l}2 \\
(3.3)\end{array}$ & - & - \\
\hline 5 & $\begin{array}{l}\text { The doctor told me everything } \\
\text { about my patient's condition }\end{array}$ & $\begin{array}{l}35 \\
(58.3)\end{array}$ & $\begin{array}{l}21 \\
(35.0)\end{array}$ & $\begin{array}{l}2 \\
(3.3)\end{array}$ & $\begin{array}{l}2 \\
(3.3)\end{array}$ & - \\
\hline & Total score & $\begin{array}{l}160 \\
(53.3 \%)\end{array}$ & $\begin{array}{l}129 \\
(43.0 \%)\end{array}$ & $\begin{array}{l}6 \\
(2.0 \%)\end{array}$ & $\begin{array}{l}4 \\
(1.4 \%)\end{array}$ & $\begin{array}{l}1 \\
(0.3 \%)\end{array}$ \\
\hline
\end{tabular}

The overall score calculated from the responses showed that $63.6 \%$ agrees that they are satisfied with verbal responses provided to them by health service providers, followed by strongly agrees (25.8\%), neutral (6.5\%), disagree (3.1\%) and strongly disagree options (1.0\%) (Shown in Table 3).

Table 3: Satisfaction with the verbal response given to the caregivers on their concerns and queries

\begin{tabular}{|c|c|c|c|c|c|c|}
\hline \multirow{3}{*}{ S.N } & \multirow{3}{*}{ Statement } & \multicolumn{5}{|c|}{ Opinion } \\
\hline & & $\begin{array}{l}\text { Strongly } \\
\text { Agree }\end{array}$ & Agree & Neutral & Disagree & $\begin{array}{l}\text { Strongly } \\
\text { disagree }\end{array}$ \\
\hline & & $\mathrm{N}(\%)$ & $\mathrm{N}(\%)$ & $\mathrm{N}(\%)$ & $\mathrm{N}(\%)$ & $\mathrm{N}(\%)$ \\
\hline 1 & $\begin{array}{l}\text { Doctor pay attention and listened very } \\
\text { carefully to what I had to say. }\end{array}$ & $\begin{array}{l}24 \\
(40)\end{array}$ & $\begin{array}{l}35 \\
(58.3)\end{array}$ & $\begin{array}{l}1 \\
(1.7)\end{array}$ & - & - \\
\hline 2 & $\begin{array}{l}\text { Nurse pay attention and listened very } \\
\text { carefully to what I had to say. }\end{array}$ & $\begin{array}{l}24 \\
(40)\end{array}$ & $\begin{array}{l}33 \\
(55.0)\end{array}$ & $\begin{array}{l}1 \\
(1.7)\end{array}$ & $\begin{array}{l}2 \\
(3.3)\end{array}$ & - \\
\hline 3 & $\begin{array}{l}\text { Nurse talking with me politely and } \\
\text { respectfully. }\end{array}$ & $\begin{array}{l}22 \\
(36.7)\end{array}$ & $\begin{array}{l}30 \\
(50.0)\end{array}$ & $\begin{array}{l}3 \\
(5.0)\end{array}$ & $\begin{array}{l}3 \\
(5.0)\end{array}$ & $\begin{array}{l}2 \\
(3.33)\end{array}$ \\
\hline 4 & $\begin{array}{l}\text { Doctor talk with me politely and } \\
\text { respectfully. }\end{array}$ & $\begin{array}{l}18 \\
(30.0) \\
\end{array}$ & $\begin{array}{l}37 \\
(61.7)\end{array}$ & $\begin{array}{l}4 \\
(6.7) \\
\end{array}$ & & $\begin{array}{l}1 \\
(1.7)\end{array}$ \\
\hline 5 & $\begin{array}{l}\text { Nurse give information to me about } \\
\text { visiting an hour. }\end{array}$ & $\begin{array}{l}10 \\
(16.7)\end{array}$ & $\begin{array}{l}30 \\
(50.0)\end{array}$ & $\begin{array}{l}14 \\
(23.3)\end{array}$ & $\begin{array}{l}5 \\
(8.3)\end{array}$ & $\begin{array}{l}1 \\
(1.7)\end{array}$ \\
\hline
\end{tabular}




\begin{tabular}{|c|c|c|c|c|c|c|}
\hline 6 & $\begin{array}{l}\text { The nurse keeps good eye contact and } \\
\text { proper facial expression while talking } \\
\text { with me }\end{array}$ & $\begin{array}{l}10 \\
(16.7)\end{array}$ & $\begin{array}{l}45 \\
(75.0)\end{array}$ & $\begin{array}{l}3 \\
(5.0)\end{array}$ & $\begin{array}{l}2 \\
(3.3)\end{array}$ & - \\
\hline 7 & $\begin{array}{l}\text { The nurse keeps good eye contact and } \\
\text { proper facial expression while talking } \\
\text { with me }\end{array}$ & $\begin{array}{l}10 \\
(16.7)\end{array}$ & $\begin{array}{l}45 \\
(75.0)\end{array}$ & $\begin{array}{l}3 \\
(5.0)\end{array}$ & $\begin{array}{l}2 \\
(3.3)\end{array}$ & - \\
\hline 8 & $\begin{array}{l}\text { The doctor keeps good eye contact and } \\
\text { proper facial expression while talking } \\
\text { with me }\end{array}$ & $\begin{array}{l}6 \\
(10.0)\end{array}$ & $\begin{array}{l}50 \\
(83.3)\end{array}$ & $\begin{array}{l}2 \\
(3.3)\end{array}$ & $\begin{array}{l}1 \\
(1.7)\end{array}$ & $\begin{array}{l}1 \\
(1.7)\end{array}$ \\
\hline & Total score & \begin{tabular}{|l|}
124 \\
$(25.8 \%)$ \\
\end{tabular} & $\begin{array}{l}305 \\
(63.6 \%)\end{array}$ & $\begin{array}{l}31 \\
(6.5 \%) \\
\end{array}$ & $\begin{array}{l}15 \\
(3.1 \%) \\
\end{array}$ & $\begin{array}{l}5 \\
(1.0 \%) \\
\end{array}$ \\
\hline
\end{tabular}

The overall score calculated from the responses showed that $50.6 \%$ agrees that they are satisfied with nonverbal responses provided to them by health service providers, followed by strongly agrees $(36.3 \%)$, neutral (9.4\%), disagree (3.1\%) and strongly disagree (0.6\%) options (shown in Table 4).

Table 4: Satisfaction with non-verbal communication by the service providers

\begin{tabular}{|c|c|c|c|c|c|c|}
\hline \multirow{3}{*}{ S.N } & \multirow{3}{*}{ Statement } & \multicolumn{5}{|c|}{ Opinion } \\
\hline & & $\begin{array}{l}\text { Strongly } \\
\text { Agree }\end{array}$ & Agree & Neutral & Disagree & $\begin{array}{l}\text { Strongly } \\
\text { disagree }\end{array}$ \\
\hline & & N (\%) & $\mathbf{N}(\%)$ & N (\%) & $\mathbf{N}(\%)$ & $\mathbf{N}(\%)$ \\
\hline 1 & $\begin{array}{l}\text { Nurse show patience while talking } \\
\text { with my patient. }\end{array}$ & $\begin{array}{l}24 \\
(40)\end{array}$ & $\begin{array}{l}30 \\
(50.0)\end{array}$ & $\begin{array}{l}2 \\
(3.3)\end{array}$ & $\begin{array}{l}3 \\
(5.0)\end{array}$ & $\begin{array}{l}1 \\
(1.7)\end{array}$ \\
\hline 2 & $\begin{array}{l}\text { Nurse show an empathetic ap- } \\
\text { proach while talking to me. }\end{array}$ & $\begin{array}{l}11 \\
(18.3)\end{array}$ & $\begin{array}{l}33 \\
(55.0)\end{array}$ & $\begin{array}{l}8 \\
(13.3)\end{array}$ & $\begin{array}{l}8 \\
(13.3)\end{array}$ & - \\
\hline 3 & $\begin{array}{l}\text { Nurse helps me to ask a question } \\
\text { with a doctor. }\end{array}$ & $\begin{array}{l}30 \\
(50.0)\end{array}$ & $\begin{array}{l}26 \\
(43.3)\end{array}$ & $\begin{array}{l}2 \\
(3.3)\end{array}$ & & $\begin{array}{l}2 \\
(3.3)\end{array}$ \\
\hline 4 & $\begin{array}{l}\text { The nurse performs good ward } \\
\text { orientation(Doctors round, Waste } \\
\text { Disposal, Drinking water, Toilet). }\end{array}$ & $\begin{array}{l}30 \\
(50.0)\end{array}$ & $\begin{array}{l}23 \\
(38.3)\end{array}$ & $\begin{array}{l}5 \\
(8.3)\end{array}$ & $\begin{array}{l}2 \\
(3.3)\end{array}$ & - \\
\hline 5 & $\begin{array}{l}\text { The nurse performs the good hand } \\
\text { movement and body language } \\
\text { while talking with me. }\end{array}$ & $\begin{array}{l}9 \\
(15.0)\end{array}$ & $\begin{array}{l}36 \\
(50.0)\end{array}$ & $\begin{array}{l}14 \\
(23.3)\end{array}$ & $\begin{array}{l}1 \\
(1.7)\end{array}$ & - \\
\hline 6 & $\begin{array}{l}\text { The doctor performs the good } \\
\text { hand movement and body lan- } \\
\text { guage while talking with me. }\end{array}$ & $\begin{array}{l}7 \\
(11.7)\end{array}$ & $\begin{array}{l}40 \\
(66.7)\end{array}$ & $\begin{array}{l}12 \\
(20.0)\end{array}$ & $\begin{array}{l}1 \\
(1.7)\end{array}$ & - \\
\hline 7 & $\begin{array}{l}\text { I am happy with the communica- } \\
\text { tion of the nurse of this hospital. }\end{array}$ & $\begin{array}{l}32 \\
(53.3)\end{array}$ & $\begin{array}{l}27 \\
(45.0)\end{array}$ & $\begin{array}{l}1 \\
(1.7)\end{array}$ & - & - \\
\hline 8 & $\begin{array}{l}\text { I am happy with the communica- } \\
\text { tion of the doctor of this hospital. }\end{array}$ & $\begin{array}{l}31 \\
(51.7)\end{array}$ & $\begin{array}{l}28 \\
(46.7)\end{array}$ & $\begin{array}{l}1 \\
(1.7)\end{array}$ & - & - \\
\hline & Total score & $\begin{array}{l}174 \\
(36.3 \%)\end{array}$ & $\begin{array}{l}243 \\
(50.6 \%)\end{array}$ & $\begin{array}{l}45 \\
(9.4 \%)\end{array}$ & $\begin{array}{l}15 \\
(3.1 \%)\end{array}$ & $\begin{array}{l}3 \\
(0.6 \%)\end{array}$ \\
\hline
\end{tabular}

Table 5 depicts that out of the total, 36.0\% strongly agreed, $53.0 \%$ agreed, $7 \%$ were neutral whereas, $3 \%$ disagreed and $1 \%$ strongly disagreed on the statement. 
Table 5: Overall agreements status with total positive statements on communication

\begin{tabular}{|l|c|c|}
\hline \multicolumn{1}{|c|}{ Agreement status } & Number & Percentage \\
\hline Strongly agree & 458 & 36.1 \\
\hline Agree & 677 & 53.3 \\
\hline Neutral & 85 & 6.7 \\
\hline Disagree & 38 & 3.0 \\
\hline Strongly disagree & 12 & 0.9 \\
\hline Total & 1270 & 100.0 \\
\hline
\end{tabular}

\section{DISCUSSION}

This study was conducted to assess the satisfaction level of caregivers towards the communication of health service providers at tertiary care hospital. The present study found that $40 \%$ of the age group of family caregivers were of 31- 40 years. Johansson, .et al. ${ }^{18}$ and Clack, et al. ${ }^{19}$ described that age of caregivers as important for his or her perception of satisfaction towards the communication of health service providers. Studies have evidenced that the increment in the young age group caregivers helps in the improvement of the health-related support services. ${ }^{20}$ We believe that the large participation of young age group as caregivers in the present study could be due to their high level of literacy than other age-group, ${ }^{21,22}$ their high level of understanding and communicating ability, ${ }^{23}$ and possibly may be due to their better health condition than any age-groups. ${ }^{24}$

The present study showed that the majority of respondents (81.7\%) speak the Nepali language. Bartlett, G.et al. ${ }^{11}$ and Anoosheh, M. et al. ${ }^{25}$ stated that language barriers affect communication and that decreases the quality of care. The probable reason for the good level of satisfaction in the present study among caregivers with health care providers could be the understandable languages used during the communication. Studies have evidenced that there might be structural and socioeconomic barriers to access the health care services when there is no consistency in the language spoken by the patients and health care providers. ${ }^{26}$ There can be a chance of adverse events and medical errors when there is a language as a communication barrier between patients and health care providers.
The current study showed that most of the caregivers strongly agreed that the communication with the health service providers was needed for their satisfaction, i.e.related different ways of communication about the patient's condition and treatment $(53.3 \%)$, verbal $(63.6 \%)$ and non-verbal (50.6 \%). Hyrkas, K. et al..$^{27}$, and Fleischer, S. et al. ${ }^{28}$ stated that all the interviewed patients described the characteristics of the nurse as objective, friendly, pleasant, empathetic, good listening, helpful and caring. Ruiz-Moral, et al. stated that the level of satisfaction is affected by communication. ${ }^{9}$ Research has shown that proper communication with the patient is a crucial factor for enhancing patient satisfaction as well as better patient outcomes. ${ }^{29}$ The good level of satisfaction among caregivers with all modes of communication suggests the importance of all the modes of communication during the diagnoses, treatment and caring process during hospitalization for caregivers' satisfaction.

In the present study, 36.4\% strongly agreed, $53.0 \%$ expressed as agreed and $3 \%$ disagreed and 1\% strongly disagreed with an overall evaluation of communication. This shows that most of the caregivers were satisfied with the different ways of communication of health service providers during patients' hospitalization for a minimum of 3-7 days. Utley-Smith, Q. et al. ${ }^{30}$ stated that the problem of the relationship between doctor and patient included deserting the patient, devaluing patient's or family's view, delivering information poorly and failing to understand the patient's and/or family's perspective of the feeling of being rush, being neglected and lack of test performance. Ruiz-Moral, R., et al. also stated that improved communication between provider and practitioner has been shown to result in good health outcomes of the patients. Therefore, there is a growing focus on improving the way that health service provider communicates and consult with families and caregivers. ${ }^{9}$ Therefore, the observation from the present study shows that health providers might be delivering the service properly to the patients.

The health service provider needs to know what factors influence caregivers' satisfaction towards communication. It is an important measure of the evaluation of a health service provider. Proper 
communication is an important aspect of patient care, which improves the nurse-patient relationship and has a profound effect on the patient's perceptions of health care quality and treatment outcomes. It is the key element in providing high-quality nursing care and leads to patient satisfaction and health.

\section{CONCLUSION}

The current study concluded that the level of communication between health care providers and family caregivers. Communications play an important role and family caregivers were satisfied with the services provided by health care professionals of the hospitals. The study finding may be helpful to the administration for enhancing proper communication between staff and patients and to maintain the quality of communication between caregivers and health service providers.

Limitations of the study: The selection of samples with convenient sampling might affect the result of the present study. The study was limited to Kathmandu Model Hospital only so the findings cannot be generalized to other settings and national levels. This is the single-center study and family caregivers from in-patients, medical and surgical wards were only included.

Acknowledgment: The author (s) would like to acknowledge Kathmandu Model Hospital for permitting conduct study and all the respondents of the study.

\section{REFERENCES}

1. Reinhard SC, Given B, Petlick NH, Bemis A. Supporting family caregivers in providing care. 2008. [Pubmed | Full Text]

2. Hines $\mathrm{S}, \mathrm{McCrow} \mathrm{J}, \mathrm{Abbey} \mathrm{J}$, et al. The effectiveness and appropriateness of a palliative approach to care for people with advanced dementia: a systematic review. JBI library of systematic reviews. 2011;9(26):960-1131. [Pubmed]

3. Walton MK. Supporting family caregivers: communicating with family caregivers. The American journal of nursing. 2011;111(12):47-53.[Pubmed]

4. Cossette S, Cara C, Ricard N, Pepin J. Assessing nurse-patient interactions from a caring perspective: report of the development and preliminary psychometric testing of the Caring Nurse--Patient Interactions Scale. International journal of nursing studies. 2005;42(6):673-686.[Pubmed]

5. Kelley JM, Kraft-Todd G, Schapira L, Kossowsky J, Riess H. The influence of the patient-clinician relationship on healthcare outcomes: a systematic review and metaanalysis of randomized controlled trials. PloS one. 2014;9(4):e94207. [Pubmed | Full text]

6. Buller MK, Buller DB. Physicians' communication style and patient satisfaction. Journal of health and social behavior. 1987;28(4):375-388.[Pubmed]

7. Vogel D, Meyer M, Harendza S. Verbal and nonverbal communication skills including empathy during history taking of undergraduate medical students. BMC Med Educ. 2018;18(1):157-157. [Pubmed $\mid$ Full text]

8. Olusina AK, Ohaeri JU, Olatawura MO. Patient and staff satisfaction with the quality of in-patient psychiatric care in a Nigerian general hospital. Social psychiatry and psychiatric epidemiology. 2002;37(6):283-288. [Pubmed | Full Text]

9. Ruiz-Moral R, Perez Rodriguez E, Perula de Torres LA, de la Torre J. Physician-patient communication: a study on the observed behaviours of specialty physicians and the ways their patients perceive them. Patient education and counseling. 2006;64(1-3):242248. [Pubmed | Full Text]

10. Cherlin E, Fried T, Prigerson HG, SchulmanGreen D, Johnson-Hurzeler R, Bradley EH. Communication between Physicians and Family Caregivers about Care at the End of Life: When Do Discussions Occur and What Is Said? Journal of palliative medicine. 2005;8(6):11761185. [Pubmed]

11. Bartlett G, Blais R, Tamblyn R, Clermont RJ, MacGibbon B. Impact of patient communication problems on the risk of preventable adverse events in acute care settings. CMAJ : Canadian Medical Association journal = 
journal de l'Association medicale canadienne. 2008;178(12):1555-1562. [Pubmed]

12. Mosadeghrad AM. Factors influencing healthcare service quality. International Journal of Health Policy and Management. 2014;3(2):77-89. [Pubmed]

13. Subedi D, Uprety K. Patients' satisfaction with hospital services in Kathmandu. Journal of Chitwan Medical College. 2014;4(3):25-31. [Full Text $\mid \underline{\text { DOI] }}$

14. Shrestha S, Devkota R. Patient Satisfaction in Nepal Medical College Teaching Hospital. Nepal Med Coll J. 2017;19(4):196-203. [Full text]

15. Koirala M, Koirala ML. Contributing Factors for Perceived Satisfaction with Nursing Care among Inpatients in General Wards. Journal of Lumbini Medical College. 2015;3(2):34-37. [Full Text $\mid$ DOI]

16. Gupta BS, Shrestha S, Thulung BK. Patient's perception towards quality nursing care. Journal of Nepal Health Research Council. 2014;12(27):83-87. [Pubmed | Full text]

17. Lionakis N, Mendrinos D, Sanidas E, Favatas G, Georgopoulou M. Hypertension in the elderly. World J Cardiol. 2012;4(5):135-147.[Pubmed | Full text]

18. Johansson P, Oléni M, Fridlund B. Patient satisfaction with nursing care in the context of health care: a literature study. Scandinavian Journal of Caring Sciences. 2002;16(4):337344.[Pubmed | Full text]

19. Clack GB, Allen J, Cooper D, Head JO. Personality differences between doctors and their patients: implications for the teaching of communication skills. Medical education. 2004;38(2):177-186.[Pubmed | Full text]

20. Ali L, Ahlstrom BH, Krevers B, Sjostrom N, Skarsater I. Support for young informal carers of persons with mental illness: a mixedmethod study. Issues in mental health nursing. 2013;34(8):611-618. [Pubmed]

21. Berens E-M, Vogt D, Messer M, Hurrelmann K,
Schaeffer D. Health literacy among different age groups in Germany: results of a cross-sectional survey. BMC Public Health. 2016;16(1):1151-1151. [Pubmed]

22. Lee EJ, Lee HY, Chung S. Age Differences in Health Literacy: Do Younger Korean Adults Have a Higher Level of Health Literacy than Older Korean Adults? Health \& social work. 2017;42(3):133-142.[Pubmed]

23. Yorkston KM, Bourgeois MS, Baylor CR. Communication and aging. Phys Med Rehabil Clin N Am. 2010;21(2):309-319. [Pubmed]

24. Bowling A. Do older and younger people differ in their reported well-being? A national survey of adults in Britain. Fam Pract. 2011;28(2):145155. [PubMed]

25. Anoosheh $\mathrm{M}$, Zarkhah $\mathrm{S}$, Faghihzadeh $\mathrm{S}$, Vaismoradi M. Nurse-patient communication barriers in Iranian nursing. International nursing review. 2009;56(2):243-249.[Pubmed | Full text]

26. Schyve PM. Language Differences as a Barrier to Quality and Safety in Health Care: The Joint Commission Perspective. Journal of General Internal Medicine. 2007;22(2):360-361. [Pubmed]

27. Hyrkas K, Paunonen M. Patient satisfaction and research-related problems (Part 2). Is triangulation the answer? Journal of nursing management. 2000;8(4):237-245. [PubMed | Full Text]

28. Fleischer S, Berg A, Zimmermann M, Wüste $\mathrm{K}$, Behrens J. Nurse-patient interaction and communication: A systematic literature review. Journal of Public Health. 2009;17(5):339-353. [DOI $\mid \underline{\text { Full Text }]}$

29. Azizam NA, Shamsuddin K. Healthcare Provider-Patient Communication: A Satisfaction Study in the Outpatient Clinic at Hospital Kuala Lumpur. Malays J Med Sci. 2015;22(3):56-64. [Pubmed $\mid$ Full Text]

30. Utley-Smith Q, Colon-Emeric CS, LekanRutledge D, et al. The Nature of Staff Family Interactions in Nursing Homes: Staff Perceptions. Journal of aging studies. 2009;23(3):168-177.[Pubmed | Full text] 